\title{
Ethnicity and politics
}

This chapter provides some theoretical perspectives to support the arguments of this book. First it examines concepts that link political change at the national level and ethnic politics to support the main argument that the politics of the Dayaks of West Kalimantan have always been constrained by the nature of the regime. The next two sections link ethnic identity formation and past marginalization with the particular nature of Dayak politics that are quite different from those of Malays, the other dominant ethnic group in the province. The next-to-last section explores related theories of ethnic conflict as a framework for the sub-arguments that the massive conflict between the Dayaks and Madurese were nonpolitical, although at the end they strengthened Dayak politics.

\section{POLITICAL CHANGES AND ETHNIC POLITICS}

Discussions of the ethnic politics of the Dayaks should be traced back at least to the sultanates and colonial times, when Dayaks had little or no political involvement or influence. This condition changed after WWII when the post-war pro-Dutch government allocated to the Dayaks important political roles in the province. From that time onwards, the course of Dayak politics has experienced changes corresponding to political transformation at the national level throughout the nation's postindependence history. The question addressed here is to what extent the transformation at the national level influences political changes at local or regional level, or more specifically, Dayak politics? 
Prior to colonial power, political structures in Asia and Africa manifested stratified social and political systems. ${ }^{1}$ In such structures, the ruler and family occupy the top level followed immediately by other members of the aristocracy and government officials. This top layer of social class enjoys many privileges. At the bottom level usually sit commoners or even slaves who had the fewest number of rights but many obligations. In many cases, this hierarchy was maintained after the colonial power took charge.

The colonial powers were aware of the negative effects of social stratification, but many chose not to rectify the problems initially. Colonial administrators found it was much easier to rule massive colonies and their huge populations, like India and African territories, through existing ruling authorities. Furthermore, changing the existing social system would de-stabilize the colony because it undermined the legitimacy of loyal local rulers and upset existing social arrangements. In fact, some colonial policies, such as favouritism, further entrenched the division between the ruler and the ruled among natives, or exacerbated the social division in their colonies (Mulinge and Lesetedi 1998:19-20).

The majority of Dayaks in West Kalimantan who lived under the rule of Malay sultanates were excluded from participation in government of any kind. The discriminatory policies of sultanates and the low social status of the Dayaks impeded their development compared with that of other ethnic groups. As many Dayaks were non-Muslim, the chances of their recruitment into the Islamic sultanates bureaucracy were remote. The highest position a Dayak could attain in the sultanates' political structure was that of village chief. ${ }^{2}$ Since most were uneducated and illiterate, the Dayaks were not qualified to work in colonial offices. ${ }^{3}$ Under such constraints, opportunities for upward social mobility were

\footnotetext{
Many past sultanates and kingdoms in parts of the world had a stratified social and political system. Reminiscent of such social stratification in contemporary societies is the use of aristocratic titles among the descendants of aristocratic families. In West Kalimantan, some individuals still retain titles such as syarif, gusti, uray, abang, and uti, which denote specific social class or public function.

2 A few smaller sultanates in the upper Kapuas were ruled by more recent Dayak converts to Islam, who had become Malay. The issue of identity change will be discussed later in this chapter.

3 The governance and administration of the sultanates was mostly under the Malay sultans and aristocrats. Most civil servants in the colonial offices came from Java and Sumatra, as well as from Christian regions, such as Minahasa, Ambon and Batakland. For an indication of the role of these non-native civil servants in West Kalimantan see the name and ethnic origin of the victims of Japanese atrocities in 1943-1944 published in the province official newspaper, Borneo Shinbun, 1-7-1944.
} 
bleak. A few Dayak revolts against the sultanates were suppressed with the help of the Dutch military.

Beginning in the nineteenth century, Catholic missions started to set up schools for Dayaks in the interior. Prior to that, Dayak access to basic education was very limited because the few schools were usually reserved for the aristocrats who had means to pay tuition. Another factor that discouraged Dayaks was the distance to schools, which were usually established in sultanate capitals and in towns. ${ }^{4}$ Although the Dayaks were lukewarm about the schools initially, they nevertheless started to take advantage of education provided by the missions. Through education, Dayaks had access to print materials, an important channel for political awakening. ${ }^{5}$ Education is also an important channel for vertical social mobility; the Dayaks started to fill white-collar jobs as teachers, nurses or mission personnel. ${ }^{6}$ Work in the sultanate administration was still closed to them because of religious bias. The political impact of the mission schools only became evident after WWII when the government allowed Dayaks to play a role in provincial politics. Former mission school students were the first to be appointed to government posts.

The change of colonial masters in 1942 from the Dutch to the Japanese had important implications for Dayaks. As each colonial master had particular values and interests (Rothermund 1995:3), the Japanese occupation brought changes to Indonesia which was then known as the

\footnotetext{
4 Horowitz mentioned that the colonial government decided on the location of facilities such as schools, transport ports, and business centres. Ethnic groups who lived nearby would take full advantage of these facilities (Horowitz 1985:151-3). In a similar vein, Hechter argued that the uneven wave of modernization (in this case the availability of modern facilities such as schools, road and seaports) could increase the gap between advanced and less advanced groups (or between the core and peripheral area). The lack of modernization would relegate the less advanced group into an inferior position (Hechter 1975:9, 39-40).

5 The importance of education in the rise of nationalism, a form of political awakening, has been noted in many parts of the world (Anderson 1991:71, 116; Rejai 1995:42; Tennesson and Antlöv 2000:872; Kahati 2003).

6 The role of education in vertical social mobility is evident in the case of the Minahasan (North Sulawesi) and Ambonese (Maluku). Formal education arrived much earlier in these regions than it did in other parts of Indonesia (Jones 1977:8; Lundstrom-Burghoorn 1981:24) which made their population more prepared to take on white-collar jobs when they became available. Both ethnic groups had been a significant source of civil servants and army recruits during this time (Jaspan 1959:7; Kahin 1964a:197). As explained earlier, significant numbers of native civil servants in West Kalimantan were also from these regions.
} 
Netherlands Indies. ${ }^{7}$ One important change brought by the Japanese was the reversal of racial classifications that existed during the Dutch colonial period. ${ }^{8}$ Europeas nationals and the Dutch language that had been signs of superiority for so long suddenly became symbols of pariah status. ${ }^{9}$ The status of native Indonesians, in contrast, was elevated overnight from the lowest to the highest social stratum below the Japanese (Wertheim 1955:42-3). Another relevant contribution of the Japanese occupation was the dismantling of special prerogative to the aristocratic group (Wertheim 1955:44), which further eroded the sultanates' authority in some regions. In Kalimantan, specific regulations of the sultanates, which were maintained during the Dutch colonial period, were abolished (Kalimantan 1953:102). The Japanese occupation also contributed to the creation of more egalitarian masses through intensive mass mobilization (Wertheim 1955:44). More directly linked to the province was the massacre of all sultans, large numbers of native aristocrats and intellectuals, Chinese merchants and influential figures between 1943 and 1944 (Borneo Shinbun, 1-7-1944). All of this together with the weakening of the sultanates system was psychologically important for the Dayaks, who always had been in the lowest layer of racial stratification in many parts of the province.

The defeat of the Japanese in WWII opened up the return of the old colonial powers in Southeast Asia. In some places, their return faced resistance from the population of their former colonies, some of whom

\footnotetext{
7 Scholars have found that colonial powers tend to have different policies and attitudes towards the colonies (Rothermund 1995:3; Souffrant 2000:138; Young 2001:17; Lane and Ersson 2002:216). Depending on many factors, even the same colonial power might act differently in different colonies (Rothermund 1995:3; Young 2001:17). As will be discuss later in this chapter, the Dutch divided the governance of the Netherlands Indies into direct and indirectly ruled regions. The Japanese occupation had army and navy administration. Kalimantan, Sulawesi and other eastern regions were under naval administration, while Java and Sumatra were under the army. Both administrations had slightly different approaches, attitudes and policies towards the regions and their population (fapanese military administration 1968).

8 The Dutch stratified social classes in the Netherlands Indies into three. The first class was occupied by European, Japanese, Turks and other elite individuals from other ethnic groups. This was the highest social class with the highest number of privileges. The Asian Far Eastern groups (vreemde oosterlingen) such as the Chinese, Indians and Arabs constituted the second class. The third and the lowest social class with the fewest privileges was the native population (inlanders). For the racial classification in the Netherlands Indies, see for example Cribb and Kahin 2004:362-4; Zainuddin 1970:157.

9 Dutch and English languages had been banned, and because Japanese was little known, Indonesian had become the major language used for government propaganda, and in schools (fapanese military administration 1968:218-9). The Japanese also interned all Europeans, except nationals of Japan's allies (Ricklefs 2001:248, 251).
} 
had been offered, and even granted, independence. ${ }^{10}$ It was in this context that the former colonial powers needed even more cooperation from segments of the community to support their smooth return, similar to what they had done when they first came into contact with these regions centuries ago. In Indonesia, the returning Dutch sought support from peripheral groups, aristocrats and sultans who were anxious about their future as the nationalist movement had grown strong across the nation. ${ }^{11}$ In West Kalimantan, beside the newly installed sultans, representatives of the Malays and Chinese, the Dayaks were included in the executive board at the provincial and district levels of government. This was the first time for Dayaks to be involved in the political process, because previously it was all handled by the sultans and Malay aristocrats with some supervision from the Dutch colonial government. The Dutch support of the Dayaks was unprecedented but it was necessary to secure the support of the Dayaks for implementation of its scheme to turn Indonesia into a pro-Dutch federal state. As will be explained in the next chapter, unlike many Malays, the majority of Dayaks of West Kalimantan was detached from the nationalist movements emanating from Java, and therefore relatively easy to persuade. The result was that as the Dayaks became one of the staunchest supporters of the Dutch for the federal states.

All of these colonial powers managed to return to their colonies, but in some cases their stay was brief. In the Philippines, Burma and Indonesia, colonial masters departed before 1950, Indochina in 1954, and the Malaya Federation in 1957. Some of these new governments, particularly those which had fought a series of wars with the returning colonial masters, had strong anti-colonial outlooks. Not uncommonly, such new governments exclude former collaborators with the colonial government from important roles in the government. In Indonesia, after a few years of war and failure to effectively re-occupy its colony, the Dutch finally recognized Indonesia's sovereignty in 1949. The new antiDutch government had adversely affected the political fortunes of many

10 The British resumed their rule in Malaya and Burma, France in Indochina, the US in the Philippines, and the Dutch in the Netherlands Indies. Previously, the Japanese had granted Burma and the Philippines nominal independence in 1943 and promised that Indonesia would gain independence in 1945 (Kratoska 2001:4-5).

11 During this time armed conflicts between the aristocrats and nationalist elements had occurred in some places. The sultans in East Sumatra as well as ulebalang in Aceh, both were known to have been supporters of the Dutch in the past, had become victims (Reid 1979). The Chinese who had cooperated well with the colonial powers and prospered during the colonial time also suffered as anti-Chinese riots flared in several places in Indonesia after WWII (Mozingo 1976:40). 
prominent Indonesians who formerly supported the Dutch. ${ }^{12}$ Those who were associated closely with the now defunct member states of federal Indonesia (RIS) and were hostile to nationalist ideas were outside the arenas of regional and national politics (Feith 1962:74). ${ }^{13}$

The fate of many individuals in the West Kalimantan Special Region Government (DIKB) was no different. Sultan Hamid II, the head of the DIKB and one of the staunchest supporters of the federal state, was arrested in April 1950 because of his role in an abortive coup. ${ }^{14}$ Dayak officials in the DIKB who were also ardent supporters of the pro-Dutch federal state, vanished from provincial politics. With the exception of two Dayak figures who were members of the national legislature at the time of DIKB dissolution and who continued to serve in those positions until 1956, other Dayak figures in the DIKB lost their political influence. The new nationalist government discontinued ethnic representation in the government and also abolished ethnic institutions set up by the Dutch, such as offices of Dayak Affairs and Chinese Affairs. Such ethnic politics was seen as a remnant of colonial policies of divide and rule and was highly unpopular during the peak time of nationalism in the early 1950s. ${ }^{15}$ Although there was animosity toward the Dayaks, as was evident in intense polemics after the Dutch departure in 1950 over political issues after the Dutch departure (Keadilan, 5-5-1950; Suar, 5-5-1950), Dayak

\footnotetext{
12 One indication of such sentiment was the excision of the Dutch language from the school system. After 1950 the second language in Indonesian school system was English, not Dutch (Reid 2005:70). Another indication was the nationalization of Dutch enterprises in 1958. This was partly a result of the Netherlands' refusal to settle the status of West Papua as mandated by the 1949 agreement between the two countries (Ricklefs 2001:316-7). Continuing repatriation of Dutch nationals from Indonesia was another indicator of hostility towards the Dutch. Between 1945 and 1964, about 250,000 Dutch had been repatriated. The peak was in 1957-1958 when about 40,000 Dutch were repatriated from Indonesia, mostly against their will (Ohliger 2005:49).

13 There were a few exceptions for former officials who displayed nationalist attitudes or who had facilitated the final departure of the Dutch. One example was Ide Anak Agung Gde Agung, the former prime minister of the State of East Indonesia (NIT) whose role was split between supporting the Dutch federalist idea and helping the creation of the sovereign Indonesia (Agung 1996; Robinson 1998a:103). He was made ambassador to a few European countries and then foreign minister in the 1950s (Roeder 1971:18). Other exceptions were those who served as members of the national legislature between 1945 and 1949, as their memberships were extended up until 1956, when new members were sworn in after the 1955 election.

14 Persadja 1955. At the time of the arrest, Hamid was a state minister of RIS, which was formed in December 1949. After his release in mid-1960s, he was not given any further formal political positions and died in 1978.

15 Feith (1962:74) observed that nationalism was at its zenith in 1950 and such ethnic sentiments and regionalism were not popular. Such sentiments reappeared from the mid-1950s when the regions felt their needs had been ignored by the central government.
} 
civil servants, whose numbers were still small, continued to serve in the bureaucracy. The Dayak Unity (PD), a political organization established after WWII, survived during this high tide of nationalism and would soon play an important role for the comeback of Dayak politics in the subsequent government.

Indonesia experienced a period of liberal democracy between 1950 and 1957. The national politics of this period was characterized by the increased role of political parties and the extensive role of parliament, and regional politics were relatively free from interference from the central government. During this period the first general election and local elections were held in the mid-1950s to elect members for national and local legislatures. The liberal system allowed ethnic and regional political parties, and even individuals, to contest the election (Feith 1957:61-2). National politics at this time were unstable because of frequent changes of government (Hadiwinata 2003:50). The discussion of the future of the constitution of the nation was stalled in the Konstituante (Constituent Assembly) by differences between members who wanted to strengthen the influence of Islam in the constitution and those who opposed such a proposal. ${ }^{16}$ Regional politics were unsettled as rebellions erupted in several regions because of dissatisfaction with the central government. Supported by the military, President Soekarno took the initiative in July 1959 and announced the dissolution of parliament and return to the 1945 Constitution, which returned governing power to the president. ${ }^{17}$ A year later, Soekarno abolished the existing parliament and established a new one whose members were appointed by the president not elected.

Such political changes at the national level have again affected Dayak politics in West Kalimantan. The abolition of the DIKB in 1950 excluded Dayaks from politics, but they had gained power by the end of 1950s. The Dayak Unity Party (PD), which survived the political transition, fielded candidates in both general and provincial elections where they outperformed most of the big national parties. These successes paved the way for the return of Dayaks to the legislative and executive bodies in West Kalimantan. With its significant representation (and therefore sig-

\footnotetext{
16 Konstituante was a body established in 1955 to formulate a new constitution to replace the provisional 1950 Constitution. It never completed its task and was dissolved in 1959 because of persistent disagreement among its members over the issue of foundation of the state (Cribb and Kahin 2004:90). ${ }_{17}$ Liddle 1999:58. In the previous constitution, the head of government was the prime minister, while the president was only a titular head of the state with little direct influence on the work of the government (cabinet). For the support of the military, see Feith 1994:23; Ricklefs 2001:320; Hefner 2000:45.
} 
nificant voting power) in the legislature, and helped by the fragmentation of Malay politics, ${ }^{18}$ and the support of central government for native rule, Dayaks were able to win several executive posts: four Dayaks were elected as district heads and one as a governor. Without a democratic election and conditions mentioned above, it would be very difficult for the Dayak to attain such positions. Remember, the Dayaks ardent support for the pro-Dutch DIKB was still fresh in the minds of opposing local leaders, who now occupied most of the government positions. If allowed to do so, they would have limited the entry of the Dayaks into politics.

Rising regional revolts in parts of Sumatra, Sulawesi, West and East Java, as well as South Kalimantan at the end of the 1950s led the government to tighten control over regional politics. ${ }^{19}$ The central government announced a regulation in 1959 requiring a political party to have branches in at least a quarter of the provinces. This regulation was particularly adverse to the regional political parties which only had a limited number of branches. ${ }^{20}$ The PD failed to satisfy the requirements, and had to disband. Its dissolution ended the relatively solid and united course of Dayak politics, as it was their main political machinery. The majority of PD members joined the nationalist Partindo, while the remainder joined the Catholic and other political parties. By merging with a national and open party, they no longer had their own independent ethnic voice. Dayak political influence was also weakened by the reduction in their representation in the parliament and other political bodies. They had to cede some of their seats to the Communists when the government introduced the concept of Nasakom. ${ }^{21}$ Fortunately, the

18 Malays were represented in all other nationalist and Islamic parties, competing with each other for political positions.

19 Some of these rebellions were the Darul Islam (House of Islam) which started first in West Java in 1948, but then spread to Central Java, Aceh, South Sulawesi, and South Kalimantan; the South Maluku Republic (RMS) in 1950; and the PRRI/Permesta revolts in parts of Sumatra and Sulawesi in 1958 (Ricklefs 2001:289-341). These rebellions were effectively defeated by mid-1958 although some of their leaders evaded capture. Sekar Marijan Kartosuwiryo, the leader of Darul Islam in West Java, was captured in 1962, and Kahar Muzakkar the leader of similar rebellion in South Sulawesi, was killed in 1965 (Ricklefs 2001:319, 326-7).

2o In April 1961, the government ordered the dissolution of all but ten political parties (Feith 1962:593).

${ }_{21}$ The concept required every important government body to have representatives from Nationalist, Religious, and Communist groups, abbreviated as Nasakom. As Partindo usually had the largest representation in the legislative or executive bodies, it was usually the first to give up some of its seats to the representative of communist group when the government implemented the concept. 
central government continued to support Dayak leadership in the province, although their political ascendancy did not last long.

From the beginning of the 1960s, politics at the national level had swung toward the left as the president's relations with Partai Komunis Indonesia (PKI, Indonesian Communist Party) and leftist elements drew closer. $^{22}$ As a result of penetration of national politics into the region, which is also known as nationalization of local politics, the president leftist and revolutionary outlook was emulated by leaders of the region. ${ }^{23}$ The aftermath of the alleged Communist coup in September 1965, which eventually brought down Soekarno, swung the political tide to the right. Supported by the army, anti-Communist religious groups and mobs initiated violence against the Communists and their sympathizers. Millions suspected of having links with Communists were either killed or detained without trial (Cribb 1990). Victims included important figures in the government such as ministers, members of parliament, and military leaders.

Drastic power shifts at the national level again affected the regional level. The drive against communists was particularly murderous in areas where communist activities were strong such as in East and Central Java, Bali, and North Sumatra (Crouch 1978:64, 155). True, some regional leaders were sympathetic to or even members of, PKI. ${ }^{24}$ However, many others who were not linked to the Communist structure, but were simply following or implementing pro-left policies as directed from Jakarta, also were swept from power. The new regime doubted their loyalty because of their close relations with Soekarno.

The Dayaks' political role in West Kalimantan was adversely affected by such change as most of its government elite had links with Partindo, which at the national and the local level was known to be close to PKI (Robinson 1998a:211; Rocamora 1970:229, 412; Van der Kroef

22 Crouch 1978:51-68; Ricklefs 2001:327-41. Soekarno's close relationship to the PKI was a consequence of its enthusiastic support for his ideas. Soekarno also needed a strong PKI to balance the influence of the army on the national political front. See, for example, Feith 1964b.

${ }_{23}$ In this process the cleavages in diverse localities became more uniform and congruent with the cleavages at the national level (Kesselman 1974:364).

${ }_{24}$ Listed as Communist allies were governors of Bali and North Sumatra, deputy governors of Jakarta, West, Central and East Java. Six out of 39 district heads and mayors in Central Java and Yogyakarta, eight of 37 in East Java, and two of 23 in West Java were from PKI (Crouch 1978:77-8). According to a foreign office evaluation, in Kalimantan, the East Kalimantan Governor A. Pranoto and Central Kalimantan Tjilik Riwut were categorized as PKI sympathizers, while West Kalimantan Governor Oevaang Oeray was a member of Partindo but categorized as a non-PKI sympathizer (Poulgrain 1998:262). 
1971:123, 219). Dayak affiliation with Partindo was, as previously explained, a result of a new government regulation on political parties. The roots of Partindo in West Kalimantan, therefore, were quite different from the party at the national level which had started with some leftist or radical roots. ${ }^{25}$ Nevertheless, as was the case in other regions, leaders in West Kalimantan, including those Dayaks who held top jobs, pursued the same leftist politics championed by the president or at least did not resist the left-swing. ${ }^{26}$ Unfortunately, the New Order regime suspected their loyalty and removed all the Dayak district heads and the Dayak governor in 1966. The majority of native leadership in West Kalimantan was soon replaced by non-native leadership. While there were only one or two native district heads, none of them were Dayaks. This trend of appointing non-locals to head the strategic positions was not only confined to West Kalimantan but also occurred in other regions.

The Dayaks would continue to be marginalized politically until the end of the New Order. Most positions available to locals would eventually fall to Malay bureaucrats, the more 'advanced' ethnic group. ${ }^{27}$ The Dayaks were generally silent about this marginalization fearing of retribution from the regime. The majority of ethnic activities during this time were, therefore, non-political. They usually concentrated on cultural, social or educational programs, such as those conducted by a few Dayak NGOs under Pancur Kasih since the 1980s.

An authoritarian regime, such as Indonesia's New Order and Soekarno's Guided Democracy, is characterized by limited or no political

${ }_{25}$ Rocamora mentions that Partindo was formed by members of PNI who were dissatisfied with the soft approach of the PNI leaders (Rocamora 1975:229). In its 1962 leadership structure, National Partindo had I.R. Lebo, K. Werdojo, A.M. Hanafi, Armunanto, Adisumarto, Oei Tjoe Tat (Bintang Timur, 30-12-1961). These individuals were incriminated by the New Order regime for their alleged leftist activities.

$26 \quad$ Many regional leaders who were very anti-PKI were replaced after 1962 by those who were either close to PKI or at least were less belligerent toward PKI (Feith 1964b). Sometimes, it was the local legislature who decided to elect a leftward leaning figure to head their regions. In Tana Toraja, Partai Kristen Indonesia (Parkindo, Indonesian Protestant Party) which dominated the local DPR decided to elect a local Partindo leader as district head in 1964, in the hope that such political compatibility with the leftward central government would benefit Toraja (Bigalke 2005:268).

${ }_{27}$ According to Horowitz (1985:147) an advanced group usually 'disproportionately well educated and represented in the civil service and the independent professions, or disproportionately wealthy and well represented in business'. Advanced ethnic groups may be a minority that dominate the government, such as the White under the apartheid regime of South Africa. Such a minority-ruled government often restricts the emancipation of the majority to minimize the possibility of political challenges. 
pluralism and the repression of opposition or challenges. ${ }^{28}$ Under such a regime, ethnic politics, which are often linked with regional politics or even separatist movements, is repressed because it is perceived as a threat to national unity. In such cases, the regime controls and monitors ethnic activities to ensure they will not endanger country unity and challenge the regime. It appoints trusted, reliable and often non-local officials to head all strategic and important positions at the local level, to ensure complete subordination. It was not uncommon for the regime to rotate or circulate the leadership to prevent such leaders building a local power base. The regime regularly rewards compliance and punishes defiance in order to keep challenges and opposition to a minimum.

Under repressive systems, most ethnic groups and their elites have no other options except pledging loyalty to the regime. Other possible options, flight and voice are either not practical or too risky. Flight is not a practical option because migrating to other countries is becoming more difficult due to the rigidity of state boundaries, while avoiding state power by fleeing to interior areas is possible but impractical. Voicing one's concerns is risky because the regime usually punishes those who challenge its policies (Eriksen 1993:123; Gurr 1993). As a consequence, large-scale ethnic activities challenging the New Order regime are not known, except in cases of ongoing separatist movements in Aceh, East Timor, or Papua. Discourses on ethnic and religious issues were monitored closely by the New Order, and those who raised the issues ran the risk of being charged with sedition. Similarly, there were no fresh regional rebellions during the last years of authoritarian Guided Democracy. Most regional revolts which started during the liberal era or earlier had been largely subdued by the early 1960s. Existing ethnic activities were more of a social and cultural nature which seemed to be safe as they posed no threat to the regime. The 'voice' option usually becomes possible after the authoritarian regime falls and is replaced by more democratic governments, as can be seen from the surge of regional and ethnic political dynamics after 1998 Indonesia.

The fall of the New Order in May 1998 signified the beginning of the democratization and decentralization process in Indonesia. Freedom House, a well-known non-governmental organization that keeps track of countries' freedoms, has noted the continuous increases of political

${ }_{28}$ For a detailed characterization of authoritarianism under the New Order, labelled as bureaucracticauthoritarianism, see King 1982:109-12. 
freedom and civil liberty in Indonesia since $1998 .^{29}$ Fair and free multiparties elections were held after more than forty years, the constitution that entrenched executive power was changed, the role of the military has been significantly reduced, and many other democratic measures were implemented. Compared internationally, the country has also been transformed from the most centralized to one of the most decentralized countries in a relatively short time (Aspinall and Fealy 2003:3; Bell 2003:117; Charras 2005:87).

An established democratic government's views on ethnic issues or ethnic movements differ from those of centralized authoritarian regimes. Democratic governments generally no longer see ethnic differences as threats to national unity and therefore are not obsessed with integrating or co-opting ethnic voices like the centralized and authoritarian countries. These governments allow ethnic movements to grow, and some governments even permit groups with separatist goals to operate. ${ }^{30}$ They also celebrate differences by adopting multi-culturalism, an ideology that allows the coexistence of diverse cultural and ethnical groups within a nation (Cashmore 2004:28-90). The Indonesian government after 1998 has been very relaxed about the rise of local politics, which was commonly intertwined with ethnic or religious interests. The government, however, has remained prohibitive toward ethnic organizations or activities that aimed for political separation. ${ }^{31}$ Looking at the result of the local elections in West Kalimantan and election trends in other regions since the fall of the New Order, it can be safely said that the majority of top jobs at the local or regional level such as governor and district head, have been returned to the local people or putra daerah. Under the New Order regime such extreme trends would have been inconceivable.

\footnotetext{
29 Freedom House changed the status of Indonesia from 'not free' to 'partly free' in 1998-1999, and 'free' after 2006. During the partly free period between 1998 and 2005, it observed the continuing expansion of the political rights and civil liberty in the country; http://www.freedomhouse.org/country/ indonesia (accessed 19-1-2012).

3o The federal government of Canada, for example, allows political parties that strive for Quebec's independence to conduct their activities. It has permitted several referenda for independence in Quebec to take place (Joireman 2003:Chapter V). For further discussions on the views of democratic states towards the minority rights or minority nationalism, see Kymlicka 2004:26-7.

${ }^{31}$ On this position, Dewi Fortuna Anwar, a political scientist who was working as the spokesperson for President Habibie argued that '... the 26 provinces of Indonesia including Aceh and Irian Jaya are fully integrated into Indonesia, and are recognized by the whole world and have been recognized by the United Nations. So it is not really to be expected that Indonesia as it stands will tolerate insurgency movements in other parts of the country' (http://news.bbc.co.uk/1/hi/talking_point/forum/443600. stm, accessed 26-10-2010).
} 
Democratization provides space for elite political manoeuvring at the national as well as regional and local level. The elite of regions who have been subjected to heavy control from the central government in the past use their newly found political freedom to push for autonomy or even independence. Leaders of ethnic groups demand cultural recognition, better economic entitlement, greater autonomy, or independence (Kellas 1991:57-60). The new democratic regime that tries to satisfy demands (for example by implementing decentralization and granting greater autonomy to the regions) may have to face greater demands with more serious implications (Kellas 1991:58). Some countries that experience rapid democratization after sudden regime change face serious political consequences including the break-up of the country or civil wars. The democratization which started in the former Soviet Union in 1989 not only brought down the Communist regimes in Eastern Europe, but also triggered unprecedented regional and ethno-nationalist movements in the region. The Soviet Union, Yugoslavia, and Czechoslovakia disintegrated into almost two dozen new sovereign states; ethnic conflicts flared in various parts of the region. ${ }^{32}$

Similarly, the unexpected fall of the New Order regime in 1998 changed the political landscape at the central and regional level. Some peripheral regions asked for better deals such as extra financial contribution from the central governments. Some of the rich regions, such as Aceh, Papua, Riau, and East Kalimantan, even threatened to pursue independence if the situation did not improve (Emmerson 2005:26-7). Local bureaucrats or politicians sidelined by Jakarta's preference for non-local leadership in the past also moved to reclaim their political rights as putra daerah (Sukma 2003:70). Elements of communities disadvantaged by the previous regime, including marginalized ethnic groups and minorities, demanded that the government address their grievances. Internal conflicts also erupted in some regions. In West Kalimantan, local politics first featured energetic Dayak political lobbies in 1998 and 1999 that resulted in the appointment of two Dayaks as district heads. The province also suffered a serious ethnic conflict in 1999, only two year after the previous one.

32 Fifteen new sovereign states emerged from the former of Soviet Union, five from former Yugoslavia, and two from Czechoslovakia. East and West Germany was integrated by the same wave of democratization that erupted in the Soviet Union. 
THE FORMATION OF ETHNIC IDENTITY

The literature on identity formation contains three main approaches: primordialism, instrumentalism and constructivism (Fenton 2003:88; Joireman 2003; Yang 2000). Primordialism understands ethnicity as ascribed; ethnic boundaries are fixed or immutable and determined by common ancestry (Yang 2000:42). According to Geertz (in Eller 1999:73), the main markers of ethnicity are blood ties, race, language, region, religion and custom. ${ }^{33}$ Constructivism, on the other hand, argues that ethnicity is not permanently determined but socially constructed; ethnic boundaries are flexible and can change over time according to historical and structural circumstances (Yang 2000:44-6). Instrumentalism stresses the ways in which ethnicity can be used as an instrument or strategic tool to achieve certain goals. People become ethnic and remain ethnic when their ethnicity generates substantial benefits to them. Ethnicity, like class and nationality, is also a means of political mobilization for advancing group interests (Yang 2000:46). Ethnicity, in this perspective, becomes relevant and important as a result of political and sometimes economic processes, and not as a result of deeply rooted or primordial ties. ${ }^{34}$

None of these approaches can by itself explain all ethnic phenomena. One approach may be more powerful in explaining ethnic phenomena in certain societies, eras and conditions, but it may have less influence in other circumstances. Primordialism cannot explain the phenomenon of identity change, or the emergence and disappearance of ethnic identities (Cornell and Hartmann 1998:50; Yang 2000:43). While most researchers now find that constructivist and instrumentalist approaches are more convincing (Laitin 1998:11-2), both approaches also have

33 Other scholars gave more detailed markers. Keyes (in Nagata 1981:92) identified kinship, descent, birthplace, and race as the most common primordial elements; and identified language and religion as secondary elements. Harold Isaacs (Cornell and Hartmann 1998:48) provided an extensive list of primordial elements: physical appearance (including size, shape, skin colour); a person's name; the history and origins of the group one is born into; one's nationality or other group affiliation; the language one first learns to speak; the religion one is born into; the culture one is born into; and the geography and topography of the place of birth.

34 Spencer and Wollman 2002:69. The last two approaches, constructivism and instrumentalism, are closely linked (Cornell and Hartmann 1998:59; Wright 2000:60). Some experts make no clear-cut differentiation between the two; some even put them in one camp (Nagata 1981:89; Kipp 1993; Williams 1994:57; Cornell and Hartmann 1998:59; Eller 1999:78; Bellamy 2003:7). 
limitations because of their disregard for primordial ties. ${ }^{35}$ This has led to the formulation of combined or integrated approaches. One of these integrated approaches recognized ethnicity as 'socially constructed partly on the basis of ancestry or presumed ancestry and more importantly by society, that the interests of ethnic groups also partly determine ethnic affiliations, and that ethnic boundaries are relatively stable but undergo changes from time to time' (Yang 2000:48).

The integrative approach seems to better explain many aspects of the identity formation of the Dayaks and their politics in West Kalimantan. Dayak identity has a primordial foundation in that many members of the Dayak ethnic group share relatively similar characteristics. However, elements of constructivism are also evident in the formation of Dayak identity. First, the term 'Dayak' was coined rather recently and was not in use several hundred years ago. The Dayak identity is not a fixed and ascribed identity and its boundaries have changed over time. For example, the Punan, who inhabit north-eastern West Kalimantan, are now widely recognized as part of the Dayak ethnic group although originally they were not. Also, Dayaks themselves can change their self identification to Malay if they convert to Islam. Besides constructivism, the influence of instrumentalism is also observable in identity association of the native that has changed over time depending on risk-benefit assessment. Initially the indigenous person was reluctant to be associated with the term 'Dayak' due to its pejorative connotation. But the attitude of many native people changed after the image and prestige of the Dayaks improved - for example, when Dayaks were accorded favourable political

35 Social construction of ethnicity cannot occur without some references to primordial elements. The formation of Japanese-American identity, for example, is unlikely without the trait of Japanese ancestry. Social construction is also constrained by observable primordial traits such as skin colour or physical appearance. Pure Chinese descent, with Chinese features, cannot be easily constructed into white, Black, or Latino (Yang 2000:49). Instrumentalism has limitations because not everyone can freely choose their ethnic identity since identity is subject to ancestral constraints (Yang 2000:47). Also, not all ethnic choices are based on rational and materialistic calculation. Psychological satisfaction, which is usually linked to emotional attachments (primordialism), also contributes to decision-making. Instrumentalism cannot explain why people persevere and keep their association with a particular ethnicity, although such identification had made them suffer (Eller 1999:79). This irrationality is better explained by primordialism (Scott in Eller 1999:79). 
treatment. ${ }^{36}$ Dayaks who converted to Islam therefore chose to become Malays because of benefits associated with that affiliation.

Dayaks are an ethnic group according to an external construction. The term 'Dayak' was first used by the Bornean Malays to describe hundreds of native tribes in Kalimantan, but not including the nomadic Punan. The term was then popularized by European explorers through their writings (Lumholtz 1920, I:23). The term had already been used by the Dutch as far back as the mid-eighteenth century (Pringle in King 1993:30). For these outsiders the native had similarities that justified such a label. The natives had symbols and characteristics that were strikingly different from the Malays and other non-Kalimantan natives. Many of the native groups shared similarities in attire, body arts (such as tattoo and long earlobes), festivities and customs. Although some were nomadic, most lived in interior regions in longhouses, lived on swidden agriculture, and practiced headhunting. They initially practised traditional animism, but later on also became Catholics and Protestants. Not being a Muslim used to be one of the most significant determinants of Dayak identity, at least in West Kalimantan.

Such an umbrella ethnic label was nonexistent for the native. For some of them, Dayak was just another word in their vocabularies, which means interior or people. ${ }^{37}$ Some of these natives might have close kinship ties, but they initially did not see themselves as members of the same ethnic group. Some of the closest groups, such as Iban and Kantuk, had even been at war in the past. The negative connotations associated with the term 'Dayak', such as savagery, backwardness, destitution, and stu-

\footnotetext{
$3^{6}$ This identity re-association is not uncommon in the study of ethnicity. Since the 1960 s, there has been a trend in democratic countries to take affirmative action to improve the conditions of indigenes or minorities. The status of being minorities or indigenous, therefore, can become advantageous. In the United States, there are increases in 'white' American claims to their indigenous or tribal status since the 1960s. Previously, many Americans with native-Indian ancestry tended to be reluctant to claim their ethnic heritage because of the social stigma and certain disadvantages of self-identifying with Native Americans (Nagel cited in Yang 2000:52-3).

37 The native Iban, for example, used the term to mean human being, while other natives, such as Tunjung, Benuaq, and Kenyah, understood it to mean interior or upstream (Whittier 1973:12-3; Lahajir M.S.Z. et al. 1993:4; Asyarie 2004:11-2). Some experts claim that the term as an ethnic label can be found in Lun Daye Dayaks in East Kalimantan, and in Bidayuh Dayaks in Northwest Kalimantan. Further etymological study is needed to verify their link to Dayak. More discussions on the meaning and origin of the term can be found in Maxwell (1984) and Eggan (1984:37). These natives already had ethnic labelling or identification. One compilation shows the native had identified more than 400 ethnic identities (Riwut 1958:182-206).
} 
pidity as noted by Bamba (2002b), discouraged the native from accepting such categorization. ${ }^{38}$

Scholars have confirmed the significant role of the colonial governments and their officials, religious workers and others in the construction of ethnic identity. ${ }^{39}$ They construct new ethnic groups by inventing new labels or promoting existing labels to represent new identities. Some of these new labels were not known previously by the locals, or if known, were not prominent before being applied through publications, censuses and policies. These labels reorganized existing ethnic memberships into members of new categories. Besides the Dayaks, the Torajanese of Sulawesi, and some groups in Africa, such as the Yoruba, Zulu and Tswana, emerged or became prominent only during the colonial period. ${ }^{40}$

Persistent use of this new categorization might have influenced some natives to accept the label. Some who found the term unacceptable took a longer time to actually use the label themselves, such as in the case of the West Kalimantan Dayaks. As one indication of their reluctance, there were no known organizations in the province that used the name Dayak until the end of WWII. In Central Kalimantan where the Dayak condition was relatively better, the natives were more ready to assume the Dayak label. There, ethnic association using the Dayak had appeared as early as in 1919 when the Sarekat Dayak was established. ${ }^{41}$ In West Kalimantan, the label became more attractive to the native after the post WWII government gave a political role to the Dayaks. The establishment of institutions that bore the term such as Dayak Affairs Office and Dayak Unity Party had strengthened the native association to the Dayak. Despite their enmity in the past, the bond among the natives had

\footnotetext{
$3^{8}$ In the past, insulting terms deriving from Dayak were common, such as 'Dayak kera' (Dayak monkey) or 'dayak-dayakan' (mimicking a Dayak) (KR 1992/01). The term 'Dayak kera' was a mutation from a Dutch word Dajakker, which means Dayak person. In the 'dayak-dayakan' play in Java, children would dress and act like the 'uncivilized' Dayaks (Soedjito 2005:16).

39 Brass 1991:50; Enloe 1980:348; Eriksen 1993:56; Glickman and Furia 1995:10; Kipp 1993:68.

$4^{\circ} \quad$ Cornell and Hartmann 1998:51; Eriksen 1993:94-5; Volkman 1987. Not all such processes were successful. The Alufuru, several tribes in Central Sulawesi, refused the use of the term 'Toraja' introduced by a Protestant missionary for their identification. Although the term to refer to the tribal group in Central Sulawesi started to gain popularity in academic writings and government reports, the local population continued to refuse to be associated with it. To them, 'Toraja' referred to an ethnic group in the north of South Sulawesi province (Hasan et al. 2004:124).

${ }^{4} \quad$ The Sarekat Dayak was renamed 'Pakat Dayak' in 1926. It was involved in political lobbying in Volksraad, the Netherlands Indies legislative body, to push for expanding the political rights of the Dayaks (Lontaan 1985:171-2; Riwut 1958:175-8; Usop 1994:55-6).
} 
strengthened as a result of identity construction, their similar experience of marginalization and their common political goals.

Not only were the colonial government and its officials influential in some ethnic identity formation, they were also important in incorporating the ethnic groups into a greater nation creation process. Benedict Anderson believed that many former colonies were bound emotionally through a series of internal nation creation journeys produced during the colonial government. He argued that the colonial government's uniform regulations and standards set fixed paths to development to be followed by the populations of the colony. One such route was through standardized education in which students within the colony learned from the same material and through the same language of instruction. Common meeting venues, such as school and government offices, provided places where ethnic groups from diverse backgrounds could interact with each other. As a consequence of these cultural exchanges, by the end of the colonial period, most major ethnic groups were accustomed to the idea that they had parts to play in the whole colony, and that they shared the same destiny (Anderson 1991:115-6, 121, 132).

However, not all ethnic groups within the same colonial administration experienced the same quality of nation-building pathways. ${ }^{42}$ The Dayaks of West Kalimantan, who were treated as second-class citizens and even slaves by the sultanate governments, were a good example. Dayaks had little or no access to education and office employment compared to the Malays, although both were indigenous groups. Printnationalism suggested by Anderson (1991:44-6) had little effect on the Dayaks because of their illiteracy and lack of social and political encounters with the rest of the nation. Also, only a few Dayaks experienced the nation-building process outside Kalimantan. Warnaen (2002:17) lists only 86 Dayaks who lived in Java by 1930 census, the second lowest after Torajanese (23). This number was very small compared to other ethnic

$4^{2}$ People from regions later incorporated into the colony or state (after independence) also did not experience a similar quality of nation building. In some cases, these ethnic groups did not fit well into the new nation. The cases of the East Timorese and the Papuans are illustrative of this idea (Drake 1989:55). East Timor was not a part of Indonesia until 1976, while Papua was under the Dutch until 1962. 
groups. ${ }^{43}$ As a consequence, the majority of Dayaks were relatively unaware of emerging nationalist movements in Java and Sumatra that arose in the early twentieth century.

Dayaks in the province did not shape the experience of nationbuilding as did the Javanese, Bataks, Minangkabauan, Minahasan and some other indigenous Indonesians who had travelled widely during the colonial period. ${ }^{44}$ At the national level other ethnic groups might also have had fewer opportunities than those more 'advanced' ethnic groups, but many still had opportunities to contribute at least to governance in their regions. ${ }^{45}$ The Dayaks lacked this opportunity, as most political rule was in the hands of the Malay aristocrats and native officials from Java and elsewhere.

Religion is an important determinant of Dayak identity. ${ }^{46}$ Kipp (1993:75) observes that for ethnic communities whose religious differences coincide with ethnic differences, religion is equivalent to ethnicity and the change of religion entails change of ethnicity. For ethnic groups that treat religion as an incidental and not essential ethnic attribute, a religion can be abandoned without any implications for ethnic status (Nagata

43 The census showed numbers of Acehnese in Java was 919, Balinese 993, Palembang 2,190, Makassarese 2,198, Batak 2,459, Banjarese 3,286, Bugis 4,593, Minangkabauan 5,117, Malays 17,329 (Warnaen 2002:17). From the 86 Dayak there was no breakdown of how many of them were from West Kalimantan. It is very likely that many of them were from Central Kalimantan due to the more advanced Dayak education there. The zending works in Central Kalimantan had begun more than a century earlier than the Catholic mission in West Kalimantan. Those schools for the Dayaks there were set up by the Protestant missions more than sixty years earlier than those in West Kalimantan. Several Dayak political elites in West Kalimantan in the 1960s (see Chapter 5 and 6) came from Central Kalimantan, such as Hugo Mungok, H.G. Mihing, and E.D. Tundang. For the zending and education for the Dayaks in Central Kalimantan, see Ukur 1971; H.M. Baroamas Jabang Balunus, 'Kedatangan dan penyebaran agama Katolik di tanah Kalimantan', n.y., in: Collection of H.M. Baroamas Jabang Balunus, Pontianak. 44 Drake (1989:54) noted that Batak, Minangkabauan, Minahasan, and to some extend the Ambonese were ethnic groups outside Java that had provided national leaders far out of proportion to their numbers.

45 The Torajan traditional leaders, for example, were in charge of their regions and could keep their traditional religion and culture, despite the regions being surrounded by more powerful lowland Islamic sultanates (Bigalke 2005).

$4^{6}$ Religion is also an important differentiating factor for the peoples of Bosnia (Duijzings 2000:10), Northern Ireland, Lebanon and India (Enloe 1980:248); for Jews and Arabs in North Africa and Israel; and for Malays in Malaysia and southern Philippines (Keyes 1981:7-8). Besides religion, language can become a crucial ethnic emblem, particularly in countries with significant language politics, such as in Belgium (between the French-speaking Wallons and Netherlandic-speaking Flemings) and in Canada (between the French-speaking Quebecois and the English-speaking majority). Language is also important for many ethnic groups in India, states of the former USSR, and Sri Lanka (Brass 1991:Chapter VIII; Wright 2000). Some minority enclaves who have a distinct language — such as Basques in both France and Spain, or Catalonians in Spain — take language as an important ethnic symbol (Nagata 1981:93). Language is not an essential ethnic attribute for the Dayak. 
1981:92). Mollucans or Javanese who converted to other religions, for example, will not be required to relinquish or change their ethnic identity. Social pressure for them to abandon their ethnicity is also less obvious.

For many Dayaks, at least as defined by their leaders, the Dayak identity was extended only to those who kept their traditional religion or embraced Christianity and excluded those who have converted to Islam. The reason for excluding Muslim Dayaks was that very often converts renounced their original identity and became Malays (masuk Melayu) or branched off to become a new ethnic group known as Senganan, Orang Laut, or Pekaki. ${ }^{47}$ Such differentiation influenced Dayak politics after WWII. In the 1940s, the Dayak leaders of West Kalimantan rejected Muslim Dayaks' attempts to represent the Dayaks in government, as they doubted the commitment of such converts to the Dayak cause. This shifted in the 1950s, when they started to accept a few Muslim Dayak leaders. After the fall of the New Order, the issue of Muslim Dayaks resurfaced, coinciding with the rising Dayak political profile; Dayak leaders once again rejected a Dayak Muslim to represent the Dayak in the National Assembly (MPR). In order not to disadvantage themselves politically by excluding converts who chose to retain their identities, the Dayak Customary Council (MAD) in 1999 recognized Muslim Dayaks as Dayaks if they recognized and practised Dayak culture. In 2003 many Dayak organizations were involved in a series of street protests when the government planned to change the education system in ways that some thought would have adverse consequences in the Christian schools. Still in 2003, the Dayaks of Landak district protested the appointment of a Moslem to head the Religious Affairs Bureau (Kantor Departemen Agama) as the majority of the population of the district were Christians. In 2004 they protested when the recruitment of the teachers of Christianity/Catholicism was much smaller than that for Muslims despite their greater needs.

The identity formation of the Dayaks that differed from other major ethnic groups and their lack of incorporation into the development of the Indonesian nation resulted in a quite different political path following WWII. After the war, a majority, if not all, Dayak politicians supported the Dutch. On the contrary, many Malay politicians outside the govern-

47 Scholars reported similar trends of becoming Malay after converting to Islam for the Dayaks in other parts of Kalimantan (Ukur 1971; Miles 1976:93; Riwut 1993:191; Hawkins 2000:32), the Batak of Sumatra (Dahm 2000:18-9; Kipp 1993:29, 33), and few other natives of Sumatra (Marsden 1811:26-7). 
ment, who had been influenced by nationalist movements, supported the new Republic led by Soekarno-Hatta. As a result of identity construction where religion had become an essential attribute, religious issues continued to be a factor in Dayak politics.

\section{DISADVANTAGED PAST AND CONTINUING MARGINALIZATION}

The issue of the Dayaks as a marginalized ethnic group will be noted throughout this book, as it has clouded Dayak politics since independence. ${ }^{48}$ Marginalization of the Dayaks, like the marginalization experienced by other communities, can be traced back to the colonial period. Colonial governments sometime intentionally assigned certain ethnic groups certain jobs - a labour division that often survived long after the colonial power left. Often they gave preferential treatment to certain ethnic groups by granting access to education and the acceptance into the civil service. The labour division and preferential treatment gave certain groups unequal opportunities to advance. ${ }^{49}$ In the case of West Kalimantan Dayaks, the local sultanates governed the region on behalf of the Dutch colonials. ${ }^{50}$ Some policies of these sultanates discriminated against Dayaks. The Dayaks generally had low social status and had to pay extra tax. They also had fewer or no opportunities to work for the Islamic sultanates administration because of their non-Moslem status. Because of their lack of education, the Dayaks also had very few opportunities to work for colonial offices.

After WWII the pro-Dutch government started to give a political role to the Dayaks. First it appointed several Dayaks to the executive board of DIKB, and then appointed Dayaks to head the Dayak Affairs Office at the provincial and district level. A few Dayaks were able to enter the bureaucracy as a result of the more inclusive policies of the government. Apart from those appointed positions the Dayak opportunities to join the

$4^{8}$ According to Gurr (1993:35) backwardness is the result of four historical processes: colonialism, state-building, migration, and economic development. This section will follow these processes in order to explain the process of marginalization of the West Kalimantan Dayaks.

49 Blanton, Mason and Athow 2001; Bowen 1996; Eller 1999:33-5; Horowitz 1985:151-66.

$5^{\circ}$ Dutch colonial rule was divided into two regions: that directly administered by the Dutch and that indirectly ruled by sultans. In the directly ruled region, governance of the region was handled by the Dutch officials. The governance of the indirectly ruled region was by the native sultanates. All regions in West Kalimantan, except Boven-Kapuas, Pinohlanden and Meliau, were indirectly ruled by the sultanates. 
bureaucracy remained slim. The reason is, first, as in many other regions, except in areas where social revolution had disrupted the existing traditional rule such as in Aceh and East Sumatra, the majority of the civil servants (pegawai) of the colonial period in West Kalimantan continued to work for the new republic. Secondly, Dayaks' chances of filling vacant higher positions left by the Dutch administrators were nil, as they had neither experience nor qualifications. Furthermore, the bureaucracy was dominated by Malays and civil servants from elsewhere who were unfriendly towards the Dayaks. Those in the bureaucracy could decide to block the entry of the Dayaks, whom they thought unsuited for the jobs, socially and intellectually. ${ }^{51}$

The problems of unequal access and marginalization persisted after independence as the government ignored the problems and failed to undertake any affirmative action to uplift the marginalized ethnic groups. These ethnic groups posed no strong challenges to existing conditions. Post-independence governments usually embark on nation building, a process which aims to integrate and harmonize the regional, social, political and institutional divisions of people within one community (Kuzio 1998:119). This process is required for nations composed of plural societies in order to be viable as a state and not disintegrate. ${ }^{52}$ Nation building tends to emphasize national unity and homogeneity at the expense of regional particulars, needs and identities. This nation building process, which is usually led by the majority and in accordance with the majority point of view, tends to disadvantage peripheral ethnic groups. ${ }^{53}$

Regions or ethnic groups who do not feel they fit into the current state often demand autonomy or independence from the central government. Facing such demands, the central government can offer wider au-

\footnotetext{
$5^{1}$ Such practice was common in a divided community as the dominant group wanted to maintain their privilege and dominant status (Hechter 1975:9). Such scornful views towards the Dayaks were common.

$5^{2} \quad$ The concept of plural societies was first introduced by Furnivall (1948). This concept refers to groups that are socially and culturally discrete, that were integrated through economic symbiosis (or mutual interdependence) and the political domination of one group (colonial masters). The groups were held together in a political system by the coercive force of the state, the police and the military, and not by shared values in these societies. When the strong colonial government departed, such plural societies could break apart (cited in Eriksen 1993:49). The breakup of British India into India, Pakistan, and later Bangladesh is one example. Another example which took place in different political setting was the break up Soviet Union and some countries in the Eastern Europe when authoritarian Communist regimes collapsed.

53 Kymlicka $(2004: 19,24,29)$ mentioned three options for the minority: seek integration into the majority culture, seek self government, or accept permanent marginalization.
} 
tonomy or repress the movements militarily if a peaceful solution cannot be reached. Meanwhile, the government continues the nation building aimed at reducing such problems, for example by tightening control over the region or implementing programs to integrate the problematic groups into the mainstream through population resettlement.

Politically, regional Indonesia had received little autonomy since independence until the fall of the New Order in 1998, with the exception of the first part of 1950s. In 1950, Indonesia inherited a decentralized political system from the former federal government. Despite decentralization containing the detested influence of a federal system, both political parties in the parliament and the government recognized the importance of decentralization for the region (Maryanov 1958:13-6). However, a few problems started to appear as a result of regions' dissatisfaction over the lack of implementation of decentralization programs. They felt there was a trend toward Javanization of the leadership in the region. Other issues included the unclear division of authority (pembagian kekuasaan) between the central and regional government, and uneven development where the interests of the regions had been ignored by the central government (Maryanov 1958:38-40). Such dissatisfaction led to several regional rebellions in the 1950s as mentioned above. At the end of the 1950s, government counter-measures reversed decentralization that was previously enjoyed to a certain degree by the regions. Central government regained control over the appointment of regional executives, such as governors and bupati, although it continued to support loyal local leaderships. ${ }^{54}$

The New Order regime tightly controlled regional politics and limited regional autonomy as one way to keep unity and control separatism. To ensure the loyalty of the region, the central government hand-picked its loyalists to fill strategic posts in the region and filled the local legislature with Golkar and military officers, who constituted the backbone of the regime. In some regions, local bureaucrats were left with second tier leadership positions. In the case of West Kalimantan, with the exception of the top jobs, which usually were reserved for the Javanese and or non-locals who usually had a military background, the bureau-

54 In September 1959, Soekarno rescinded the UU No. 1 1957, which allowed regional DPR to elect the governor and bupati, and returned such right to central government (Anderson 1990:49; Cribb and Kahin 2004:109; also Mackie 1999:206). 
cracy dominated by Malays. ${ }^{55}$ Dayaks were minimally represented in the bureaucracy and leadership. For these discontented ethnic groups, a solution was not easy as the voicing of concerns could be considered subversion and punished by the regime.

Consequently, the regime avoided issues that could provoke ethnic or regional sentiments. The New Order regime should have been aware of the political marginalization of the Dayaks, but bringing those issues to the surface would have destabilized local politics. Local governments, which had little representation of Dayaks, also continued to ignore the problems. In fact, there were beliefs among the Dayaks that the dominant Malays in the bureaucracy had prioritized their own ethnic group during recruitment and promotion, and therefore, limited Dayak entry to and rise in the bureaucracy. ${ }^{56}$ The affirmative policies regarding Dayaks by the post WWII government between 1945 and 1950 had been discontinued as they were seen as remnants of colonial policies of divide and rule. From the mid-1950s to mid-1960s, Dayak leaders in the executive tried to recruit more Dayak civil servants, but the effort only resulted in minor improvements in the number of Dayaks in the civil service.

Slow growth of the region's economy was a result of neglect and uneven development due in part to internal colonialism. ${ }^{57}$ The regions had complained during the 1950s that regional development had not improved (Maryanov 1958), probably the result of the wars and political instability from 1945 to the end of 1950s. The national economy received little attention during Guided Democracy, and when Soekarno lost power in 1966, the country's economy was on the brink of bankruptcy (Agung 1990:647; Vatikiotis 1998:33), so was the regional economy.

The new regime embarked on rapid economic development, but its highly centralized development strategy left out many peripheral regions.

55 The domination of military officers who were usually non-local in the top leadership at the local level also occurred elsewhere in Indonesia (Bertrand 2004:116; Sukma 2005:12).

$5^{6} \quad$ This shows that despite government disapproval of ethnic politics, local leaders could still play the ethnic card to benefit their ethnic group. Bertrand gave an example of a Muslim governor in Maluku who tried to improve the portion of Muslim civil servants in the Christian dominated bureaucracy in Maluku during the 1990s (Bertrand 2003b).

57 Internal colonialism theorists propose that the uneven development between regions is state-induced and that ethnic groups who live on the periphery are uniquely disadvantaged (Hechter 1975). However, critics of internal colonialism argue that uneven economic development within a state may not be the result of state discriminatory policies but due to natural economic forces. For example, the region was poor in natural resources or located in less strategic positions geographically for rapid economic growth (Connor 1994:149-50; Kellas 1991:62). 
Development in Indonesia had been concentrated mostly in western parts of the country, particularly in Java. The development in the eastern part of the country, such as the Kalimantan, Sulawesi, Maluku and Papua, had been very slow. ${ }^{58}$ The central government was overly enthusiastic about exploiting these regions' natural resources and slow in developing them. This uneven development was one of the reasons regions strongly supported full decentralization after the fall of the New Order. Some, including leaders of Dayak NGOs of West Kalimantan, even supported the federal system as a solution. They also opposed government development programs in areas such as logging and plantations that they thought were only benefiting the central government and big businesses but detrimental to local interests.

Socially and culturally, governments in Southeast Asia often 'develop' indigenous minorities and incorporate them into the nation state. This is an important nation-building project as governments often see these peripheral groups as a hindrance to national progress and a threat to national security. ${ }^{59}$ One way to end the backwardness of indigenous minorities is to resettle them in areas close to the general population so that they can be 'developed' and integrated into the mainstream national culture. These minorities go to school to learn the national language, convert to a recognized world religion, and enter the cash economy (Duncan 2004c:3).

Sometimes instead of removing the indigenous group, the government sends migrants to live near the indigenous population, so these can learn and benefit from the more 'civilized' migrants. In Indonesia the population resettlement program is known as transmigrasi, where population from densely populated Java, Madura, and Bali are resettled to the sparsely populated regions. ${ }^{60}$ Problematic regions such as Aceh, erstwhile East Timor, Papua, as well as regions with international borders have

${ }_{5}^{8}$ The Integrated Economic Development Zone (KAPET, Kawasan Pengembangan Ekonomi Terpadu) designed to accelerate development in East Indonesia, was only introduced in 1996. The government has established twelve KAPETs since the concept was introduced. As intended, they are all located in Eastern Indonesia: four in Kalimantan, four in Sulawesi, two in Nusa Tenggara, one in Maluku and Papua (Soenandar 2005:182). For indicators of the uneven development between the Western and Eastern Indonesia see Akita (2002;1995), Garcia (1998), Sjafrizal (1997), and Soenandar (2005:182).

59 Duncan 2004c:1-2; see also Li 1999. The term for these minorities usually contains backward and primitive connotations such as Orang Asli (the native) in Malaysia, or chaaw haw (hill tribes) in Thailand, masyarakat terasing (isolated tribes) in Indonesia (Duncan 2004b:86, 2004c:1)

6o This could be in the form of sponsored or spontaneous transmigrations. Unlike the sponsored transmigration where the government covers significant establishment costs, those who chose the path of spontaneous transmigration would receive no financial support from the government. 
received significant numbers of migrants in the past. The interior region of West Kalimantan, home region of the Dayaks, has become the target of government-sponsored transmigration since the 1970s.

While such moves are aimed at fostering national unity, frictions between locals and migrants arise because of cultural differences, land disputes, economic competition, and other issues (Otten 1986:147-84). There have been reports of local disappointment over the small financial compensation for appropriated land and lack of economic benefits to the local population (Roekaerts 1985:29; Sapardi 1992:130; Djuweng 1996:93).

These nation-building efforts may result in the assimilation of indigenous minorities into the mainstream, such as in some Southeast Asian countries (Duncan 2004a). Significant assimilation to the Malay society has occurred among many indigenes who lived under the influence of Malay culture throughout Southeast Asia (Benjamin 2002:50-4). The New Order had once put almost half of the Dayaks in West Kalimantan into the category of isolated ethnic groups (masyarakat or suku terasing) which required resettlement so they could become more like the mainstream population of Indonesia. Their shifting cultivation system, communal living in longhouses, and some traditional arts were considered dangerous, unhealthy, or too primitive. That negative perspective on their culture and traditions inflicted social and cultural stress. Their tribes also lost dignity because their traditions and culture were considered to be of no value (Eriksen 1993:123).

Marginalization caused resentment and despair in the affected regions and peripheral groups. For those who had no means to fight or to voice their concerns, the fall of the authoritarian regime provided hope. Voices demanding better treatment are usually quite united as the marginalization to the group as a whole tends to foment ethnic solidarity and to blur intra-ethnic friction. The marginalized status explains the sudden surge of energetic and relatively united Dayak politics in the 1940s and 1950 s, and in the 1990s. Marginalization also could intensify conflict when it erupts, as will be shown below.

\section{ETHNIC CONFLICT AND ETHNIC POLITICS}

The starting point of this book is that ethnic conflicts are prominent features of any multi-ethnic society. This is so because, borrowing Horowitz' 
argument (1985:144-5), ethnic groups have a natural tendency to cleave, compare and compete with each other. They also tend to cleave and favour their own kind, and negatively stereotype, distrust and do disservice to other ethnic groups. ${ }^{61}$ However, despite the enmity of inter-ethnic relations, not all ethnic groups are in conflict. There should be a more specific explanation as to what conditions make certain ethnic groups prone to conflict. To answer this question, this study adopts Michael Brown's model to explain why internal conflict occurs.

Brown (2001:5) differentiates two categories of causes of conflicts: the underlying and proximate causes. The underlying causes or permissive conditions refer to necessary conditions for conflicts to develop and explain why certain areas or ethnic groups are conflict-prone. Brown categorizes four main clusters of factors that make some places or ethnic groups more prone to violence than others: structural, political, economic/social, and cultural/perceptual factors (Table 2.1). The second category is proximate causes or triggers referring to factors that cause a conflict to escalate. ${ }^{62}$ They are rapid and unexpected changes in any of the underlying causes which ignite violent conflict. Corresponding to the underlying factors, Brown (2001:13-15) also differentiates four proximate causes (Table 2.2).

\begin{tabular}{|l|l|}
\hline 1. Structural factors & 3. Economic/social factors \\
Weak states & Economic problems \\
Intra-state security concerns & Discriminatory economic systems \\
Ethnic geography & Economic development and modernization \\
\hline 2. Political factors & 4. Cultural/perceptual factors \\
Discriminatory political institutions & Patterns of cultural discrimination \\
Exclusionary national ideologies & Problematic group histories \\
Inter-group politics & \\
Elite politics & \\
\hline
\end{tabular}

Table 2.1 Underlying causes of internal conflict

Source: Brown (2001:5).

${ }^{61} \quad$ Lijphart (1995:853) even includes those 'who tend to harbour negative and hostile feelings towards members of other groups' into his definition of an ethnic group.

62 Another quite similar model is from Michael Lund (1996), which classifies causes into structural and dynamic factors. The structural factors remotely and indirectly affect the conflict, while the dynamic factors are more direct and immediate. 


\begin{tabular}{|l|l|}
\hline $\begin{array}{l}\text { 1. Structural factors } \\
\text { collapsing states } \\
\text { changing intra-state military balances } \\
\text { changing demographic patterns }\end{array}$ & $\begin{array}{l}\text { 3. Economic/social factors } \\
\text { mounting economic problems } \\
\text { growing economic inequities } \\
\text { fast-paced development and modern- } \\
\text { ization }\end{array}$ \\
\hline $\begin{array}{l}\text { 2. Political factors } \\
\text { political transition, increasingly influential } \\
\text { exclusionary ideologies, growing inter-group } \\
\text { competitions, intensifying leadership struggles }\end{array}$ & $\begin{array}{l}\text { 4. Cultural/perceptual factors } \\
\text { intensifying patterns of cultural } \\
\text { discrimination, ethnic bashing and } \\
\text { propagandizing }\end{array}$ \\
\hline
\end{tabular}

Table 2.2 Proximate causes of internal conflict

Source: Brown (2001:13-5).

This book will look into the underlying conditions and triggers of conflicts between the Dayaks and Madurese of West Kalimantan. It will not follow all factors examined by Brown, but only will look into factors that are most pertinent to the conflicts. Brown (2001:4) himself believes that it is futile to search for a single factor or a set of factors that can explain all internal conflicts because there are many different types of internal conflicts, each with a different set of causes.

Antagonistic group history (Brown 2001:20) seems to be an important determinant of ethnic conflict. Ethnic groups tend to be hostile to others, but in reality not all ethnic groups are involved in open conflict. Examination of some major ethnic conflicts in recent times will show that the warring parties had a history of conflict or tense relations in the not-too-distant past. ${ }^{63}$ Conflicts in former states of Yugoslavia, for example, dated back to at least to WWII (Daalder 1996:38-41). Conflict between the Tutsi and Hutu in Rwanda and Burundi can be traced back at least to the early 1950s when they were still under colonial rule (Proxy targets 1998:11). The Dayaks and Madurese in West Kalimantan also have antagonistic group history since they have been involved in about a dozen conflicts since the 1950s. Such conflict history has strained the

63 While the roots of some conflicts can be traced back to centuries or millennia of antagonism (Horowitz 1985:98), many contemporary conflicts have more direct connection to the colonial or postcolonial period. The colonial preference treatment and their failure to take ethnic lines into consideration when establishing the colonies were some factors that breed post-colonial conflicts. Examining various conflicts in many parts of the world, Fearon and Laitin (2003:88) concluded that there are positive connections between past and recent conflicts. The study concludes that prevalent internal conflicts in the 1990s were the result of accumulation of protracted conflicts since 1950s, and were not due to the end of Cold War, as generally believed. 
relations between the two more than their relations with the other ethnic groups. The strained relations gave every small tension among the Dayak and Madurese the potential to develop into an open conflict.

Ethnic geography, or the concentration or spread of an ethnic group, is an important contributor to ethnic conflicts. Brown mentioned that states with ethnic minorities and with certain ethnic spreads are more prone to conflicts. The potential for conflicts are greater if ethnic groups who were historically antagonistic live close to each other. Some countries have a complex ethnic geography because their country's boundaries were established by the colonial powers without conforming to traditional ethnic boundaries, or because of some population policies in the past where the regime forcefully integrated their populations (Brown 2001:6-7). Complex ethnic geography has contributed to ethnic conflicts in post-colonial Africa (Routledge 1998:247), in the Caucasus region in Russia and in the former Yugoslavia. ${ }^{64}$

Ethnic geography seems to be pertinent to conflicts in West Kalimantan, although no studies have cogently argued such a case before. Almost all conflicts between the Dayaks and Madurese occurred in the north-western part of the province in the Sambas and Pontianak districts. The population of the Madurese in these two districts was the highest in the province and was rapidly on the rise prior to the conflicts in 1997 and 1999. The population of the Madurese in these two districts was highly concentrated and quite separated from other ethnic groups. Because of such a settlement trend it was not difficult to find the 'Madurese' villages, where the Madurese continued living in their distinctive way. The population of the Dayaks in these regions was also high. Considering their strained relations and conflict history, their population concentration close to each other only increased the potential for conflict between them.

Ongoing marginalization and discrimination suffered by an ethnic group is another underlying condition for conflict (Stewart 2002:112-3; see also Yang 2000:193). An element of marginalization is found in some major ethnic conflicts such as between Hutu and Tutsi in Burundi and Rwanda, between the Bosnians and Serbs in Bosnia-Herzegovina, and between ethnic groups in Russia's Transcaucasia (Stewart 2002:112-3).

${ }_{4}$ In the Caucasus conflicts or tensions occurred in Nagorno-Karabakh, Chechnya, Abkhazia and South-Ossetia. In the former Yugoslavia conflicts occurred in regions that have now become independent states (Koehler and Zürcher 2003:243-4). 
In Indonesia, repeated anti-Chinese riots beginning in the early twentieth century were partly a result of the relatively more dominant position of the Chinese over the local population in the local economy. Marginalization also contributed to some more recent communal conflicts in West and Central Kalimantan, Maluku, as well as conflicts with separatist goals in Papua, Aceh, and erstwhile East Timor. ${ }^{65}$ The suspicion that marginalization caused conflict in West Kalimantan is also strong, as it always involves Dayaks, the long-term marginalized natives of the province. Growing grievances and frustration because of their disadvantaged conditions make both the Dayak elite and non-elite prone to get involved in conflicts. ${ }^{66}$ The marginalization experienced by the Dayaks, both elite and commoners across different sub-ethnic groups, also strengthened ethnic solidarity among the Dayaks, which in turn accelerated the spread and severity of the conflict.

The ethnic institutions and their leaders can have a role in the conflicts. Ethnic leaders and institutions can serve the role of brokerage and information diffusers, two elements important in conflict escalation. ${ }^{67}$ Ethnic leaders are able to construct valid reasons for conflict and use

\footnotetext{
65 For communal conflicts in West and Central Kalimantan, see Bertrand 2004:58; Communal violence West Kalimantan 1997:9-11; Communal violence Indonesia 2001:13; Peluso and Harwell 2001:93; Rabasa and Chalk 2001:45; Smith and Bouvier 2006b:209-10; for communal conflicts in Maluku, see Bertrand 2003a:187; Van Klinken 2001:18-9; for conflicts with separatist goals in Papua, Aceh, and East Timor, see Bourchier and Hadiz 2003:256; Collins 2003:47.

66 Scholars have frequently quoted grievances and frustrations as sources of conflicts. Grievance is a result of unjust treatment. The hostility as a result of grievance is usually aimed at a specific group who has caused the injustice. Frustration is a result of one being blocked from one's goals. Frustrated persons may vent their anger at anyone or any groups, even if they are not the source of their frustration. For further discussion see Bartos and Wehr (2002:73-4).

${ }_{67}$ McAdam, Tarrow and Tilly 2001:333. I believe that these two factors are pertinent in conflict escalation particularly when taking into account technology advances in telecommunication and transportation. The advances of communication and transportation make possible the participation of more people, involving larger areas, and inflicting greater casualties. Nowadays, news on the conflicts, whether rumoured or true, travels instantly and is uncensored. Requests for help even from the remotest areas to friends in the region or international sympathizers can be made almost immediately. News from radio, television, and newspapers, although sometimes screened or neutralized by the broadcasters to cool the situation down, still gives out information on the conflicting parties and can contribute to the escalation. The news creates insecurity and provokes the ethnic solidarity of the members of conflicting parties who do not necessarily live adjacent to the conflict areas. They can initiate the attack in their areas because of fear of attack from their enemies or because of moral obligation to help their ethnic brethren. Better means of transportation makes possible rapid movements for those involved in conflicts.
} 
their influence to mobilize masses against the enemy. ${ }^{68}$ Ethnic organization makes possible collective action on a large scale because it provides organizational infrastructures, network links, and leadership. ${ }^{69}$ Armed ethnic organizations have a role in initiating conflicts in Sri Lanka, Myanmar, Chechnya, and Kosovo. In some other cases, the role of ethnic organizations in initiating conflict is less evident, although they still can have a role in its escalation. In the case of conflicts in West Kalimantan between the Dayaks and Madurese the initial triggers seem to be spontaneous, although there were suspicions of the involvement by military, ethnic leaders and organizations.

Proximate causes are the triggers for the conflicts. Systemic changes such as rapid democratization from the previously authoritarian regime are potential triggers for conflicts. ${ }^{70}$ Such transformations require a change of the rules of the game, where elements in the community, the political elite included, need to readjust to the new environment and to reconsider their position toward their political rivals and partners. ${ }^{71}$ Conflicts are not unusual during this uncertain transitional period. Ted Gurr (in Snyder 2000:29) concluded that while democratic consolidation reduced ethnic conflict, the first steps in the shaky transition to democra-

68 Arfi 1998:153. Unfortunately, members of the elite often manipulate ethnic movements to extract concessions from the state for their own benefit: to improve their political position or to better their social or economic status. Some other elites become involved in ethnic activities to pursue their idealistic interests. They continue to be involved in the activities despite the hostile political environment. Martin Luther King of the US and Nelson Mandela of South Africa are known for their unreserved endeavours to bring equality to the 'Blacks' in their countries. Religious leaders, such as Bishops Desmond Tutu of South Africa and Carlos Filipe Ximenes Belo of East Timor, are also known for their outspoken stance against the unfair and repressive ethnic policies of the regimes.

69 Olzak 2004:671. Ethnic organizations provide resources and networks, and prepare and coordinate the ethnic members in order to reach a better result in the conflict. Activities by ethnic organizations are usually better organized and prepared compared to spontaneous ones. An organized demonstration will equip its participants with pamphlets or leaflets, ethnic attributes, and with written demands. The possibility of success for such activities by ethnic organizations is greater because of their consistency, ability to follow up and also because they are identifiable for possible negotiation.

7o Every change in the political environment, such as a regime change, releases expectations and capabilities, or causes frustrations and resistance (Kellas 1991:60), which provide openings for conflicts to develop.

$71 \quad$ Many elites are less ideological but of rational choice and will logically try to maximize gains and minimize costs to themselves of their actions. They are pragmatic and may adjust their political attitude according to the changing environment. The rational elite change their attitudes when the regimes change. During the political transition in the mid-1960s in Indonesia, those who were linked to the leftist party tried to seek refuge in Golkar, a government political party (Bigalke 2005:276; Ward 1974:177). Post-1998 Indonesia has seen many examples of such rational actors. Members of the elite, who collaborated closely with the former regime, have detached themselves from it, and become champions of reform (Elson 2001:291-2; O’Rourke 2003:118-35). 
cy increased the potential for strife, particularly in new states. Snyder and Mansfield (2007:5) noted that countries taking early steps on the journey from dictatorship toward democracy are especially prone to conflict and violence. ${ }^{72}$ Similarly, Lund (2002) saw that the democratization has created opportunities for internal conflict, particularly if the countries are not ready to embrace liberal democracy.

Democratization opens up political participation which was tightly controlled previously. ${ }^{73}$ Struggle for power among national or local elites across ethnic and interest groups intensifies because political vacancies are no longer filled only by those who are loyal and close to the regime. Not uncommonly elite competition results in conflict at the grassroots level (Rinakit 2005:52). Demands for greater autonomy or even independence from the regions are usual where the previous governments had been highly centralized and authoritarian. Democratization also gives opportunities for the members of formerly disenfranchised or oppressed groups, for example the minority, to lobby or mobilize to demand that the government redress their problems. ${ }^{74}$ Such conditions might lead to conflict as the dominant ethnic group might want to keep its influence or the new government might not be able or ready to cope with the intense demand. ${ }^{75}$

A weakening regime and the subsequent collapse of the authoritarian regime, as well as the ensuing rapid democratization, could be linked to conflict. For Indonesia, the indicator was the increased social conflict from the mid-1990s as the New Order regime weakened. It suffered a series of massive conflicts in many regions after the sudden regime change in 1998 and rapid democratization (Agustino 2005:83-92; Tadjoeddin 2002:35). Such conditions did not themselves cause conflicts, but they provided conditions that favour conflict. For Brown (2001:6) and Bertrand (2003a:178), it was the release and the interplay of forces previ-

$7^{2}$ Previously both have jointly investigated the connection between democratization and war-proneness (Mansfield and Snyder 1995, 2005). Another scholar who has tried to establish the connection is Michael Mann (2005).

73 Democratization enabled more people to play a larger role in politics, a potential source of ethnic conflict (Snyder 2000:27).

74 Minority groups may benefit from goods traditionally associated with democracy, such as greater opportunities for political participation and greater respect for civil liberties, although democratization in some cases may also harm minority groups (Bell, Daniel 2003:38).

75 For example, the new government may give wider autonomy but reject claims for independence. When the central government is unwilling to compromise on an independence option, continuing to pursue such a goal will invite armed repression from the central government. 
ously repressed by the strong authoritarian regime that caused conflict. In the case of Dayak-Madurese conflicts in West Kalimantan, democratization and political transition after 1998 contributed to the conflict, although they had occurred many times before in periods of high political and economic stability in the 1970s and 1980s.

Other triggers for ethnic conflict include incidents or policy changes that tip the ethnic political balance or upset ethnic relations. The unexpected appointment of a district head from a certain ethnic (or religious) background could result in a high level of ethnic polarization ${ }^{76}$ and serve as a potential trigger for ethnic conflict. The failure of Dayak candidates in the 1994 election in Sintang, and the removal of Cornelis as a candidate in the district head election in Pontianak in 1999, for example, had resulted in angry Dayak mobs going on rampages. The announcement of affirmative actions might create opposition from the other ethnic groups whose interest would be negatively affected. Kidnapping, arrest, or murder of ethnic or community leaders could set off conflicts between opponent groups.

Besides systemic triggers, sometimes there are also more immediate but trivial triggers such as individual verbal disputes or street fights between members of ethnic groups can develop into significant conflicts. Such incidents have a greater potential to evolve into large-scale conflicts if they occur between members of antagonistic ethnic groups. Many other factors can contribute to the transformation of a minor incident into open conflict - for example, the timing and venue of the incidence.

$7^{6}$ Ethnic polarization is the widening gap between the political and social space of competing ethnic groups (McAdam, Tarrow and Tilly 2001:322). 